\section{The fall of the traditional lipid hypothesis}

\section{KARI SALMINEN}

This article deals with the latest developments and recommendations concerning hypercholesterolaemia and its dietary treatment in Finland. In the light of recent studies, the Finnish target value for blood cholesterol level, less than $5 \mathrm{mmol} / \mathrm{l}$ for the whole population, seems to be too low. Also the replacement of animal fats in the diet with margarines manufactured by catalytic hydrogenation, as the latest recommendation suggests, is more than questionable. The most recent findings support the hypothesis that consumption of partially hydrogenated vegetable and marine oils may contribute to the occurrence of cardiovascular heart diseases. Therefore the Finnish recommendation of December 1992, should be reviewed.

The so-called lipid hypothesis has been a predominant issue in the controversy over the role of fats in human nutrition during the past thirty years. According to the traditional hypothesis

1) a high blood cholesterol level increases the risk of coronary heart disease (CHD) morbidity and mortality, and

2) the saturated fatty acids in the diet raise, and polyunsaturated fatty acids lower, the blood cholesterol level.

According to the lipid hypothesis it would thus be logical to limit the intake of saturated fats and increase the intake of polyunsaturated fats from the diet, as numerous international and national recommendations have suggested. The development of the situation especially in Finland over the past few years is reviewed below.

\section{Finnish recommendation of 1988}

In autumn 1988 an ad hoc group of the Finnish Association for Internal Medicine and The Finnish Cardiac Society published the recommendation "Diagnosis and treatment of hypercholesterolaemia and other hyperlipidaemias in adults" (1). The target value for blood cholesterol was set at less than $5 \mathrm{mmol} / \mathrm{l}$ for the entire adult population regardless of age or sex. At the time only one in five Finns had a cholesterol level below the set limit.

Classified according to the recommendation, about half of the population had a "moderately" enhanced risk of CHD with cholesterol levels of $5-6.5 \mathrm{mmol} / \mathrm{l}$, and one third a "considerably" enhanced risk, as their cholesterol level exceeded $6.5 \mathrm{mmol} / \mathrm{l}$.

Consequently, on the basis of the recommendation, four in five Finns were deemed to require some kind of treatment to lower their cholesterol levels. Lowering the cholesterol by dietary means was emphasized in the first place, but in cases where other risk factors were found, medical treatment was recommended in addition. By 1990, the sales of cholesterol lowering drugs had grown 30 fold from the year preceding the recommendation (2).

The dietary recommendations emphasized the replacement of saturated animal fats with unsaturated vegetable oils and fats, thus placing particular pressure on the use of milk fat.

After publication, the recommendation and especially its strict limits for cholesterol values aroused certain criticism. It was, however, as late as 1992 that the Finnish Medical Journal published a critical editorial (3) and some articles on the subject $(4,5)$.

\section{New recommendation in 1992}

In December 1992 another ad hoc group assigned by five institutions, published a new recommendation on blood serum cholesterol and its diagnosis and treatment (6). The risk values for cholesterol regarding CHD were now somewhat changed. The recommendation considered the range 5$6.5 \mathrm{mmol} / \mathrm{l}$ as bearing a "mild", range $6.5-8$ "moderate" and $>8 \mathrm{mmol} / \mathrm{l}$ a "considerably" enhanced risk of CHD. The target value for a single individual as well as for the whole population remained at below $5 \mathrm{mmol} / \mathrm{l}$.

In suggesting ways to reach the target value, the new recommendation took a slightly more cautious 
attitude towards medication than the previous one. However, the suggested dietary measures and the recommendation for decreasing milk fat intake were, if possible, even stricter. Milk product consumption was to favour low fat or fat-free products, and butter was to be changed to margarine at the table and to margarine or vegetable oil in baking and frying.

\section{Weakness of the lipid hypothesis}

\section{Blood cholesterol vs. cardiovascular and total mortality}

NHLBI conference. A conference on "Low Blood Cholesterol: Mortality Associations" arranged by the National Heart, Lung and Blood Institute, NHLBI (7) included presentations from 19 cohort studies from the United States, Europe, Israel and Japan. The material consisted of 650000 individuals including reports of more than 68000 deaths. Fig. 1 shows the relationship between mortality and serum cholesterol levels of men and women.

The curves illustrating the relationship between blood cholesterol and cardiovascular mortality on the one hand and total mortality on the other are not identical. Neither are the cholesterol-mortality curves for males and females. This fact was very clearly stated at the NHLBI conference.

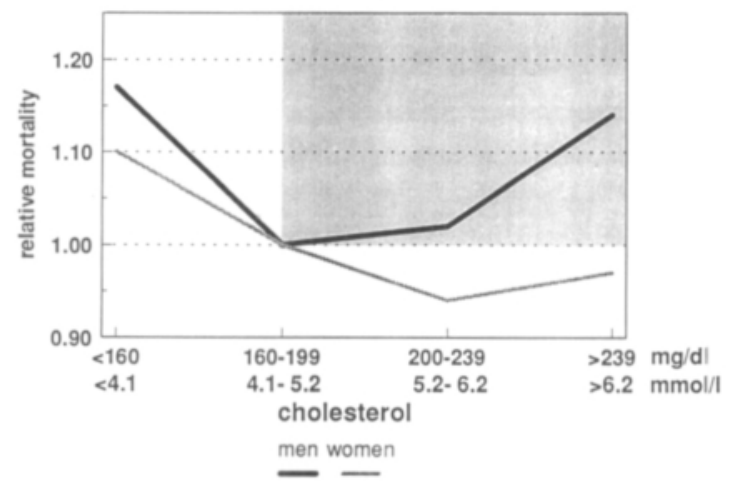

Fig. 1. U-shape describing the association between blood cholesterol level and mortality.
Based on the conference report, the editorial of Circulation, "Health Policy on Blood Cholesterol. Time to Change Directions", dealt with the cholesterol dilemma (8) drawing the following three conclusions.

\section{1) There is an association between low blood cholesterol and noncardiovascular deaths in men and women.}

The curve illustrating the relationship between blood serum cholesterol level and mortality is U-shaped (Fig. 1). The mortality of the population increases both at low and high cholesterol values, as illustrated by the rising limbs of the U-shape. The bottom part of the U-shape describes an "optimum" cholesterol level where mortality is lowest. The left-hand limb indicates mainly non-CHD mortality and the right-hand limb mainly CHD mortality.

Figure 1 shows how the mortality of men quite clearly follows the U-shape. The rising left-hand limb reflects increasing non-CHD mortality and the right-hand increasing CHD mortality.

The curve illustrating the mortality of women is less clearly U-shaped. The rising left-hand limb in the range of the low cholesterol level illustrates non-CHD mortality which is on the increase. The right-hand limb (or, rather, its absence) will be dealt with in point 2).

Referring to the first conclusion the editorial noted that it might be time to review national policies aimed at shifting the distribution of blood cholesterol of the entire population towards the left. A cholesterol-lowering diet may not be prudent for those adults whose cholesterol levels place them on the left-hand limb of the total mortality U-shape.

\section{2) There is no association between high blood cholesterol and cardiovascular deaths in women. \\ This message can be clearly seen in Fig. 1. In contrast with the evidence for men, a high choles- terol content in women does not reflect CHD mor- tality. Owing to this there is no clearly rising right- hand limb in the U-shape for women.}

This conclusion introduces a strong female perspective to the cholesterol controversy to the effect that it no longer seems wise to screen for and treat 
high blood cholesterol in women. An exception maust naturally be made with women who already have coronary disease or who otherwise are at a high risk of CHD death.

\section{3) Primary prevention trials of cholesterol inter- vention reveal an increase in non-CHD death rates that is similar in magnitude to the decrease in CHD death rates.}

According to the editorial, the above three conclusions indicate a need to change the current cholesterol recommendations. Cholesterol measurements and treatments should be limited to the minority of the population to whom the benefits would be clearly greater than the disadvantages. Thus, measures should be directed only at people who already have a coronary heart disease or a subsequent risk of $\mathrm{CHD}$.

Important SII Mobile Clinic Survey. The Mobile Clinic Survey carried out by the Finnish Social Insurance Institution (SII) should be mentioned in this connection (9). It reviews comprehensively the relationship between blood values, including cholesterol values, and mortality in the Finns.

The results of the survey are for the most part similar to those of the NHLBI conference report. The authors of the SII Mobile Clinic Survey write about blood serum cholesterol levels in the Finns as follows: "Optimum values in men appeared to be roughly between 5 and $7 \mathrm{mmol} / \mathrm{l}$, and in women between 6 and $9 \mathrm{mmol} / \mathrm{l}$."

One-sided Finnish recommendation. The Finnish recommendation (6) differs markedly from the views introduced by the NHLBI conference and the SII Mobile Clinic Survey. It is based on a study on the cholesterol levels and CHD mortality in American middle-aged men. The recommendation thus concentrates primarily on the right-hand limb of the $\mathrm{U}$-shape mortality curve of men (darkened in Fig. 1), but the conclusions are, however, applied to the entire Finnish population. This cannot and should not be done.

The editorial of Circulation ends as follows: "We need now to pull back our national policies directed at identifying and treating high blood cholesterol in the primary prevention setting and put on hold wellmeant desires to intervene while we await convincing evidence that the net effects will be beneficial."

The above shows that the Finnish recommendation looks at our national health from a very narrow angle. It is based only on the cholesterol vs. CHD mortality curve of middle-aged men.

\section{Dietary fatty acids and blood cholesterol}

The second main argument of the lipid hypothesis, which claims that saturated fatty acids raise and polyunsaturated fatty acids lower blood serum cholesterol level, is very vague. The P/S ratio, i.e. the ratio of the dietary polyunsaturated fatty acids to saturated fatty acids, has been a cornerstone of the Finnish dietary recommendations. It is now losing its significance as a result of long-lasting discussions $(10,11)$. While the $\mathrm{P} / \mathrm{S}$ ratio still occupied a central role in the 1988 recommendation, it was omitted from the 1992 recommendation.

According to the current conception:

- Only lauric, myristic and palmitic $\left(\mathrm{C}_{12}-\mathrm{C}_{16}\right)$ acids of saturated fatty acids raise the total and LDL cholesterol levels. They evidently also raise the HDL cholesterol level.

- Polyunsaturated fatty acids lower the total and LDL cholesterol levels. A high intake decreases the HDL cholesterol level. The earlier opinions emphasizing the beneficial effects of polyunsaturated fatty acids have become more cautious also because of the oxidation tendency of those acids.

- The lipid hypothesis did not take into account monounsaturated fatty acids, especially oleic acid. According to the current opinion it lowers both the total and LDL cholesterol levels without any real effect on the HDL cholesterol.

However, it is the occurrence of trans isomers of fatty acids, especially those of oleic acid, formed in the catalytic hydrogenation of vegetable oils, that now really shakes the lipid hypothesis. 
Partially hydrogenated vegetable oils and trans fatty acids. Katan and his collaborators have shown that the trans isomers of oleic acid formed in hydrogenation raise the total and LDL cholesterol and lower the HDL cholesterol $(12,13)$. Some other studies $(14,15,16,17)$ have reached a similar conclusion.

A recent article published in Lancet (18) has really caused a sensation. Harvard scientists calculated the intake of trans fatty acids from dietary questionnaires completed by 85095 women without diagnosed CHD, stroke, diabetes, or hypecholesterolaemia in 1980. During 8 years of follow-up, there were 431 new cases of CHD. After adjustment for age and total energy intake, the intake of trans isomers was found to be directly related to a risk of CHD. Additional control for established CHD risk factors, for example saturated fat and dietary cholesterol, did not change the relative risk substantially. The association was stronger for the 69181 women whose margarine consumption over the previous 10 years had been stable. Intakes of foods that are major sources of trans isomers (margarine, cookies, cake, and white bread) were each significantly associated with higher risks of CHD. The researchers concluded that these findings supported the hypothesis that consumption of partially hydrogenated vegetable oils may contribute to the occurrence of CHD.

In a study on ischaemic heart disease and consumption of hydrogenated marine oils, Thomas showed that there was an association between the disease and the trans fatty acids formed in catalytic hydrogenation (19).

The Finnish recommendation of 1992 (6) underestimates the significance of trans fatty acids and recommends the use of margarines. If the recommendation were followed, the intake of trans fatty acids from the Finnish diet would increase substantially. The European recommendation (1992) for its part states: "Hydrogenation of vegetable oils, a common industrial practice, produces trans fatty acids which behave similarly to saturated fats (20). Their intake should be minimised." Thus hard margarines and products containing hydrogenated oils should be avoided.
Table 1 shows the fatty acid compositions of three best-selling Finnish margarines, commercial milk fat-rapeseed oil mixtures and traditional butter. According to the current conception of the health effects of fatty acids, the milk fat-rapeseed oil mixtures are superior to hydrogenated margarines. Surprisingly the Finnish recommendation does not even mention these products which were, in fact, developed by the country's own dairy industry.

In the light of these most recent findings, the prudence of the Finnish recommendation concerning dietary fats can be questioned.

\section{Conclusion}

The Finnish recommendation "Diagnosis and treatment of hypercholesterolaemia and other hyperlipidaemias in adults"(6) is mainly based on the traditional lipid hypothesis. The expediency of the recommendation should be reviewed in the light of the latest studies on diet, blood serum cholesterol and mortality. According to this information:

1. The mortality of the population increases both at high and at low cholesterol levels. The U-shape (Fig. 1) illustrating mortality vs. blood cholesterol level is different for men and women. Hence, the optimum blood cholesterol range should be set for men and for women separately. The present target value, below $5 \mathrm{mmol} / \mathrm{l}$ for the entire Finnish population, is not reasonable.

2. The trans fatty acids formed in the catalytic hydrogenation process of polyunsaturated fatty acids have an unfavourable effect on blood cholesterol and may contribute to the occurrence of CHD. Thus the Finnish recommendation to increase the use of margarines is not well-founded. There are considerably better alternatives on the Finnish yellow fat market (Table 1).

\section{Kari Salminen}

Valio Ltd.

Research and Development

P.O. Box 390

FIN-00101 Helsinki, Finland 
Table 1. Fatty acid compositions $(\%)$ of three best-selling margarines, milk fat-rapeseed oil mixtures and butter.

\begin{tabular}{|c|c|c|c|c|c|c|}
\hline & \multirow{2}{*}{$\begin{array}{l}\text { Saturated } \\
\mathrm{C}_{12}-\mathrm{C}_{16}\end{array}$} & \multirow{2}{*}{$\begin{array}{l}\text { Trans } \\
\mathrm{C}_{18: 11} \\
\end{array}$} & \multirow{2}{*}{$\begin{array}{c}\text { Total } \\
\text { Sat. \& Trans }\end{array}$} & \multirow{2}{*}{$\begin{array}{c}\text { Mono- } \\
\text { unsaturated } \\
\text { Oleic acid }\end{array}$} & \multicolumn{2}{|c|}{ Polyunsaturated } \\
\hline & & & & & Linoleic acid & Linolenic acid \\
\hline Margarine 1 & 14 & 12 & 26 & 24 & 33 & 3 \\
\hline Margarine 2 & 25 & 7 & 32 & 31 & 11 & 4 \\
\hline Margarine 3 & 15 & 11 & 26 & 23 & 35 & 2 \\
\hline \multicolumn{7}{|c|}{$\begin{array}{l}\text { Milk fat-rapeseed } \\
\text { oil mixtures }\end{array}$} \\
\hline Mixture $1^{\text {a }}$ & 19 & 2 & 21 & 39 & 14 & 7 \\
\hline Mixture $2^{b}$ & 26 & 2 & 28 & 33 & 10 & 5 \\
\hline Mixture $3^{c}$ & 34 & 3 & 37 & 28 & 7 & 3 \\
\hline Butter & 43 & 4 & 47 & 20 & 1 & 1 \\
\hline
\end{tabular}

a $40 \%$ milk fat, $60 \%$ rapeseed oil

b $60 \%$ milk fat, $40 \%$ rapeseed oil

c $80 \%$ milk fat, $20 \%$ rapeseed oil

\section{References}

1. Suomen Sisätautilääkärien Yhdistyksen ja Suomen Kardiologisen Seuran työryhmän suositus. 1988. 19 p.

2. Finnish Statistics on Medicines from 1987-1991. The Finnish Committee on Drug Information and Statistics. Helsinki 1988, 1989, 1990, 1991, 1992.

3. PASANEn, A. 1992. Sepelvaltimotaudin ennaltaehkäisy arvioitava uudelleen. Suom. Lääkäril. 47: 1120-1121.

4. SAlminen, K. 1992. Onko aika määritellä kolesterolin tavoitetasot uudestaan? Suom. Laäääril. 47: 1192-1193.

5. NıккILÄ, M. 1992. Kenen poikkeavia lipidiarvoja pitäisi hoitaa? Suom. Laäkäril. 47: 1952-1956.

6. Frick, M.H., Huttunen, J., Huvinen, M., Katila, M., Kesä-Niemi, A., Kovanen, P., Miettinen, T., Ol.kinuora, J., Pyörälä, K., Sal.mi, J., Savolainen, M., Taskinen, M.-R., Tikkanen, M., Uusitupa, M., ViIKari, J. \& WINELL, K. 1992. Aikuisten hyperkolesterolemian ja muiden hyperlipidemioiden diagnostiikka ja hoito. Duodecim 109: 205-225.

7. Jacobs, D., Blackburn, H., Higgins, M., Reed, D., Iso, H., McMillan, G., Neaton, J., Nelson, J., Potter, J., Rifkind, B., Rossouw, J., Shekelle, R. \& Yusuf, S. 1992. Report of the Conference on Low Blood Cholesterol: Mortality Associations. Circulation 86: 10461060.

8. Hulley, S.B., Walsh, J. \& Newman, T.B. 1992. Health Policy on Blood Cholesterol. Time to Change Directions. Editorial. Circulation 86: 1026-1029.

9. AromaA, A. \& MaAtel. J. 1981. A search for optimum values. Prognostic evaluation of reference values. In: Gräsbeck, R. \& Ahlström, T. (eds.). Reference values in laboratory medicine. John Wiley \& Sons.
10. SAlminen, K. 1988. P/S-suhde, harhaanjohtava suure. Duodecim 104: 1562-1563.

11. Salminen, K. 1990. Ravinnon tyydyttyneet ja tyydyttymättömät rasvat. Duodecim 106: 1684-1685.

12. Mensink, R. \& Katan, M. 1990. Effect of dietary trans fatty acids on high density and low density lipoprotein cholesterol levels in healthy subjects. N. Engl. J. Med. 323: 439-445.

13. Zock, P.L. \& KATAN, M.B. 1992. Hydrogenation alternatives: effects of trans fatty acids and stearic acid versus linoleic acid on serum lipids and liporoteins in humans. J. Lipid Res. 33: 399-410.

14. Nestel, P., Noakes, M, Belling, B., McArthur, R., Clifton, P., Janus, E. \& AbBey, M. 1992. Plasma lipoprotein lipid and $\mathrm{Lp}(\mathrm{a})$ changes with substitution of elaidic acid for oleic acid in the diet. J. Lipid Res. 33: 1029-1036.

15. Troisı, R., Willett, W.C. \& Weiss, S.T. 1992. Transfatty acid intake in relation to serum lipid concentrations in adult men. Am. J. Clin. Nutr. 56: 1019-1024.

16. Lichtenstein, A.H., Ausman, L.M., Carrasco, W., JenNer, J.L., Ordovas, J.M. \& Schaefer, E. 1993. Hydrogenation Impairs the Hypolipidemic Effect of Corn Oil in Humans. Arterosclerosis and Thrombosis 13: 154161.

17. Wood, R., Kubena, K., O’Brien, B., Tseng, S. \& MarTIN, G. 1993. Effect of butter, mono- and polyunsaturated fatty acid-enriched butter, trans fatty acid margarine, and zero trans fatty acid margarine on serum lipids and lipoproteins in healthy men. J. Lipid Res. 34: 1-10.

18. Willett, W.C., Stampfer, M.J., Manson, J.E., 
Colditz, G.A., Speizer, F.E., Rosner, B.A., Sampson, L.A. \& Hennekens, C.H. 1993. Intake of trans fatty acids and risk of coronary heart disease among women. Lancet 341: 581-585.

19. Tномаs, L.H. 1992. Ischaemic heart disease and consumption of hydrogenated marine oils in England and Wales. J. Epid. and Comm. Health 46: 78-82.
20. Prevention of Coronary Heart Disease: Scientific Background and New Clinical Guidelines. Recommendations of the European Atherosclerosis Society prepared by the International Task Force for Prevention of Coronary Heart Disease. Nutr. Metab. Cardiovasc. Dis. 1992. 2: 113-156. 